\title{
Using heat maps to identify areas prone to violence against women in the public sphere
}

\author{
Margarita Garfias Royo ${ }^{1 *}$, Priti Parikh ${ }^{1}$ and Jyoti Belur ${ }^{2}$
}

\begin{abstract}
The lack of accessible crime data, especially geolocations, in developing countries often acts as a barrier to identifying environmental or situational factors in high crime areas that might contribute to the facilitation of those crimes. This paper presents a methodology for conducting fieldwork for creating heat maps to identify areas prone to violence against women (VAW) in Corregidora, Mexico. Heat maps were produced based on household survey data. The results were used to select specific high concentration locations to conduct structured observations and inductive visual analysis at street level in order to identify if and what situational factors might influence the perpetration of VAW in those locations. Four broad features were identified in the urban built environment during the site visits linked to the facilitation of opportunities for the commission of VAW: (1) lacking infrastructure, (2) presence of physical obstacles, (3) poor visibility and (4) restricted pedestrian mobility. The paper demonstrates the utility of this method for aiding situational crime prevention strategies in areas where official spatial crime data is unavailable or lacking. This study presents a relatively low cost (although labour intensive) and independent method of aiding crime prevention strategies, which will hopefully be of practical value for organisations in areas with poor crime recording practices and limited access to expensive mapping technologies.
\end{abstract}

Keywords: Violence against women, Heat maps, Density analysis, Crime mapping, Infrastructure, Built environment

\section{Introduction}

This paper presents a fieldwork methodology that used heat maps to identify areas prone to Violence Against Women (VAW) in the public sphere of five urban localities of the municipality of Corregidora, Querétaro in Mexico $^{1}$. The heat maps were used to identify locations where women appeared to be more vulnerable to violence in public places. In-depth structured observations and visual analysis at ground level were then conducted at these locations to identify features for crime prevention through environmental design. It was found that these spaces shared the following four urban built environment features: (1) lacking infrastructure, (2) presence

\footnotetext{
*Correspondence: ucesamg@ucl.ac.uk

1 Engineering for International Development Centre and Civil,

Environmental and Geomatic Engineering, University College London, London, UK

Full list of author information is available at the end of the article
}

of physical obstacles, (3) poor visibility, and (4) restricted pedestrian mobility.

This fieldwork methodology can be applied to understand gender-based violence, particularly against women, in urban settings where no official data is available, or to test the accuracy of official data with onsite field data. The heat maps created for this study were based on data collected through household surveys and produced using publicly available mapping software.

\section{Background}

\section{Violence against women}

Gender-based violence is any act of violence in which the motive of the attack is directly related to the victim's gender (McIlwaine 2013). More specifically, Violence AgainstWomen (VAW) is defined as any act of violence that is directed towards a person who socially identifies as

\footnotetext{
1 The work is part of a Ph. D. programme.
}

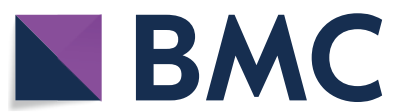

(c) The Author(s) 2020. This article is licensed under a Creative Commons Attribution 4.0 International License, which permits use, sharing, adaptation, distribution and reproduction in any medium or format, as long as you give appropriate credit to the original author(s) and the source, provide a link to the Creative Commons licence, and indicate if changes were made. The images or other third party material in this article are included in the article's Creative Commons licence, unless indicated otherwise in a credit line to the material. If material is not included in the article's Creative Commons licence and your intended use is not permitted by statutory regulation or exceeds the permitted use, you will need to obtain permission directly from the copyright holder. To view a copy of this licence, visit http://creativeco mmons.org/licenses/by/4.0/. The Creative Commons Public Domain Dedication waiver (http://creativecommons.org/publicdomain/ zero/1.0/) applies to the data made available in this article, unless otherwise stated in a credit line to the data. 
woman (Council of Europe 2011; Shepherd 2008). These acts can result or are likely to result in sexual, psychological or physical harm or suffering, and include coercion, threats, or deprivation of liberty, and can occur in public or private spheres (United Nations (UN) 1993). Feminist theories agree that the underlying causes of gender-based violence are rooted in patriarchal relations, with social control being exercised over most women and some men (with implications for their autonomy to move in public spaces) in the interests of the dominant gender, class, ethnic, religious, sexuality or age groups (McIlwaine 2013; Levy 2013).

Control over mobility can come in the form of violence as well as physical barriers, such as lack of or insufficient infrastructure (Mcllwaine 2013; Parikh et al. 2015). Some studies have found that VAW committed in the public space can be associated with spaces such as vacant fields and buildings, narrow paths, construction sites, parks, spaces with poor lighting or near public transportation (Belur et al. 2016; Willman and Corman 2013; Dymén and Ceccato 2012). This shows that women are more likely to experience violence in certain urban areas and environments than in others (Dymén and Ceccato 2012). Furthermore, risk in cities is not homogeneous; areas of mixed land use, city centres and transportation nodes tend to be more criminogenic than residential areas (ibid). Different layouts and land uses, such as the segmentation of services by major roads in large city centres and the relocation of industrial areas to the periphery of cities, can also pose different problems for women than for men (Loukaitou-Sideris 2016).

\section{Situational factors that facilitate crime}

Although the interconnections between urbanisation, violence and crime are complex, the configuration of the built environment influences the way people interact with the urban space and its community (Foster and Giles-Corti 2008; Gupte et al. 2014; Hong and Chen 2014; Oreskovic et al. 2014). Urban areas can provide the setting for various types of violence, especially when high rates of growth overwhelm government capacity to provide basic services, including security, to its residents (Gupte et al. 2014; Willman and Corman 2013). Settings that facilitate crime and fear are the by-products of the environment that humans build to support the requirements of their everyday life (Brantingham and Brantingham 1995). Conversely, local crime patterns can be used to understand how people interact with their physical environment (Felson and Clarke 1998).

Built environment elements can facilitate crime and violence by providing a space that makes them easy, safe and profitable, assisting in the interactions between potential offenders and potential targets, having an impact on the types, quantities and timings of different crimes (Brantingham and Brantingham 1995). Environmental criminology is interested in the interactions of people and their environment and argues that crime should be understood as the product of offenders, victims and their setting, including laws and time (Brantingham and Brantingham 1981). The Routine Activity Theory underpins the concept of interaction between place, offender and target; assuming that for a crime to occur, there must be a convergence in time and space of three elements: a suitable target, a likely offender and the absence of a capable guardian-any person whose presence or proximity would discourage a crime from occurring (Felson and Clarke 1998). Thus from an environmental perspective, where the crime occurs is an important element for understanding why it occurred and what can be done to prevent it. Many urban interventions that aim to prevent and reduce violence focus on situational prevention approaches, which incorporate design measures in order to reduce crime opportunities (Farrington and Welsh 2002). Crime Prevention Through Environmental Design (CPTED) aims to reduce situational opportunities for violence through infrastructure improvements (Willman and Corman 2013, p. 19), and there is evidence that situational prevention measures can reduce certain types of crimes. Some examples include improvements in street lighting associated with reduced property and vehicle theft, buildings with windows foster a sense of safety and ground-floor windows have been found to promote pedestrian activity (Oreskovic et al. 2014; Farrington and Welsh 2002). A number of studies on sexual offending against women have indicated that adopting a situational approach will reduce opportunities for crimes to be committed in public places (c.f. Leclerc et al. 2016; Cubbage and Smith 2009; King 2009; Eck 1994).

Certain attributes of the public sphere are correlated with higher incidents of crime, and give way to the creation of crime generators or crime attractors. Crime generators are accessible places to the public with large numbers of people, attracted by reasons unrelated to crime activities or criminal motivations and which lack capable guardians, thus creating opportunities for crime (Brantingham and Brantingham 1995; Ariel and Partridge 2017; Bernasco and Block 2011). There is a growing body of research that is looking at sexual offending against women in public transport as an example of crime generators in many developing countries. (c.f. Mazumder and Pokharel 2019; Gekoski et al. 2017; Ceccato and Paz 2017; Natarajan et al. 2017; Tripathi et al. 2017; Chui and Ong 2008). A number of studies have also located the solutions to VAW on public transport in situational measures (c.f. Natarajan et al. 2015; Newton 2014; 
Dunckel-Graglia 2013; Smith 2008). More research is needed to understand how other forms of urban infrastructure can provide opportunities for the commission of VAW in public spaces (c.f. Mohamed and Stanek 2019; Belur et al. 2016; Bhattacharyya 2016; Parikh et al. 2015; McIlwaine 2013; Whitzman et al. 2013; Wesely and Gaarder 2004; Massey 1994).

\section{Spatial analysis to aid crime prevention}

Studies of crime and place have identified that crime has "an inherent geographical quality" (Chainey and Ratcliffe 2005, p. 1) and a local nature to be concentrated in specific geographical areas, whether a street segment, a road intersection or a specific address. The criminology of place focuses in understanding why crime occurs at specific places, as becoming a target of crime depends on unique situational dynamics that are shaped by micro geographic opportunity structures (Cornish and Clarke 1986), and crime locations are not distributed randomly in space (Weisburd, 2015; Rossmo 2014). Crime mapping can therefore be used as a tool for supporting the different tasks central to policing and crime reduction (Chainey and Ratcliffe 2005). It can have different applications ranging from data collection to monitoring and evaluation, the design of initiatives for crime prevention, and communication with the public (ibid).

Concentrations of crime at specific locations can be referred to as hotspots-which tend to be no larger than a road intersection, street segment or a single plot of land in some cases (Ariel and Partridge 2017; Mazeika and Sumit Kumar 2017; Weisburd 2015; Bernasco and Block 2011). According to Chainey and Ratcliffe (2005), "a hotspot represents an area of high crime concentration, relative to the distribution of crime across the whole region of interest" and present accurate and specific point data (Chainey and Ratcliffe 2005; Kulyk and Sossa 2018). There is no universal standard to define the number of crimes that have to occur in an area to be defined as hot, as it depends on the average of its specific location (Eck et al. 2005).

Heat maps are an alternative tool for crime mapping. $\mathrm{Yu}$ and $\mathrm{He}$ (2017) describe heat maps as an applied method for visualising spatial patterns. In this method, the data is processed into a continuous colour distribution, and the heat, as Kulyk and Sossa (2018) describe it, derives from the high geographic concentration of events in or around a particular location. They are surface density maps (ibid) which can be used as an alternative spatial analysis approach when the available data is not suitable for hotspot analysis.

Crime mapping has been widely used in policing and crime prevention planning by law enforcement agencies around the world (Leong and Chan 2013; Chainey and Ratcliffe 2005). In Mexico, the use of crime maps is still in its early stages. The government of Mexico City is the only state in the country known to have produced georeferenced data as well as openly published crime data (Gobierno de CDMX 2020; FGJ CDMX 2020). Calderón et al. (2019) produced a national level heat map for Organized-Crime-Style Homicide, examining trends in organized crime and violence in Mexico during 2018. There have also been grassroot efforts to map some of the events of violence that occur in the country. Valle-Jones (2019) used open national data to produce data visualisations and maps of Mexico City's crime spots.

The application of crime mapping to model spatial patterns of VAW has only gained attention in recent years (Manazir et al. 2019; Mohamed and Stanek 2019; Serendipia 2019; Fontes et al. 2018). One development has been the creation of apps for informing female users of potential areas of risk, based on user reports of events of violence (Muldoon et al. 2019; SafetiPin 2020; Harassmap 2020). In Mexico, there are only a handful of examples of crime mapping of VAW. The United Nations Office on Drug and Crime (UNODC) in Mexico partnered with the State Institute of Women of the state of Nuevo León to create a state-level heat map to display the areas most at risk of VAW in Nuevo León. The project was based on official crime data recorded by different state and national institutes (López Padilla et al. 2018). An exploratory analysis aimed at identifying patterns of harassment in the metropolitan area of Querétaro was conducted by San Román Tajonar and Meza de Luna in 2019. Their data was based on a web harvesting exercise in which victims of VAW registered their attack online. At grassroot level, Salguero (2019) mapped feminicides ${ }^{2}$ reported in the media. In terms of policing, apart from the data published by Mexico City's local government, there is no evidence or other publicly available data to suggest that VAW crimes are georeferenced by the police at national, state or municipal levels.

\section{Case study context}

Corregidora municipality is located in the southwest of the state of Querétaro, Mexico (see Fig. 1). As of 2018, the municipality was divided into 59 localities which were further subdivided into 64 basic geostatistical areas

\footnotetext{
${ }^{2}$ A femicide or feminicide refers to "the murder of women because they are women, whether it is committed within the family, a domestic partnership, or any other interpersonal relationship, or by anyone in the community, or whether it is perpetrated or tolerated by the state or its agents" (OHCHR and ONU Mujeres 2014, p. 14).
} 


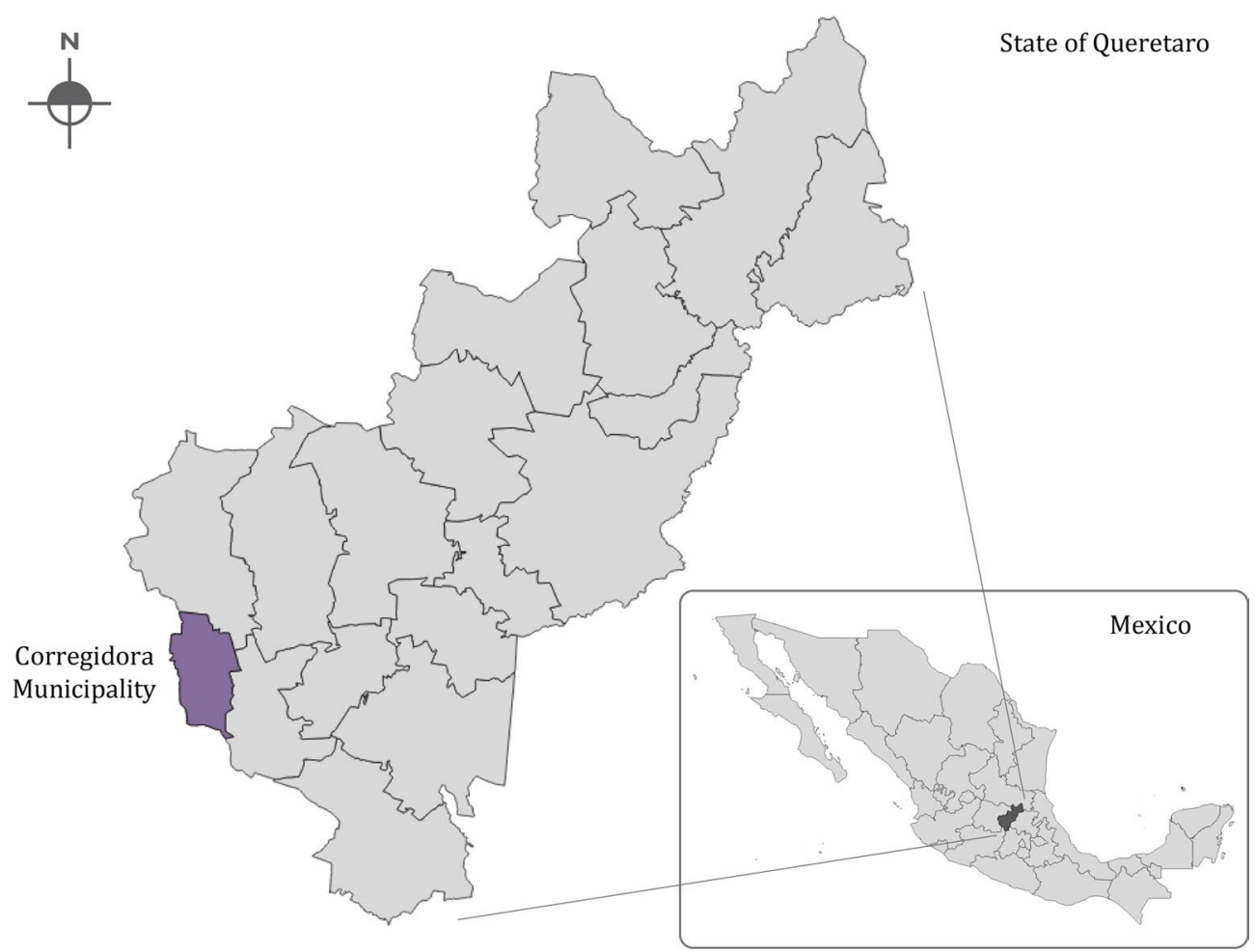

Fig. 1 Map of Corregidora (Figure by the first author with maps created with shapefiles from INEGI (2015a)

(Agebs), of which 60 were classified as urban and clustered into 6 localities $^{3}$. The urban extent of the municipality of Corregidora is part of the metropolitan area of the city of Querétaro (ibid). It is a rapidly growing municipality, with different estimates showing population growth projections ranging from $5.2 \%$ to $8 \%$ annually (Banda Campos 2017, 2019; INEGI 2015b). Despite local government efforts to plan the urban landscape (oral communication with local politicians, 2019), rapid urbanisation has allowed for unorganized, uncontrolled and exponential expansion of the municipality, which has become dispersed, distant and disconnected (Kim and Zangerling 2016). This growth has posed a challenge for the local government in terms of budgeting and planning, including delivery of infrastructure (oral communication with local politicians, 2019).

A national Mexican survey (National Survey on the Dynamics of Household Relations-ENDIREH) measured the prevalence of VAW and indicated that in the state of Querétaro $38.7 \%$ of women have been victims of gender violence by strangers in public spaces such as parks, streets and public transportation, and $66.8 \%$ of

\footnotetext{
${ }^{3}$ In 2019, however, the municipality was reclassified and one urban locality and 258 rural localities were added to the catalogue (SEDESOL 2019).
}

these aggressions were of sexual type, including offensive remarks, intimidation, attempted rape and/or rape (INEGI 2016a, 2017). However, data for this survey is aggregated at state level, not at municipality level. Apart from this survey, conducted every 5 years since 2006, official data regarding VAW is scarce. Independent and autonomous institutions tend to replace official organisations in the dissemination of data on VAW. Such is the case of Observatorio Ciudadano de Querétaro (OCQ), which reported 282 cases of VAW from July to September 2017 (OCQ 2018) and an increase of 7.57\% of VAW in 2019 compared to the previous year, but there is little contextual information to indicate what this number means (OCQ 2019). This data is difficult to find, lacks references and is usually only provided upon request. Other publicly available data includes statistics by the Mexican Secretariat of Public Security (SESNSP) regarding criminal activity across the country. However, the methodology for reporting crime-including VAWwas not standardised at national level until the beginning of 2018 and data is only available at municipal level (not locality level; SESNSP 2018). Thus, official records regarding the number of reported cases, registered pretrial investigations and/or investigation files over time 
is readily available and there are inconsistencies in the figures and types of reported crimes ${ }^{4}$. Moreover, during the course of this research, despite best efforts, it proved difficult to gain access to official crime figures from the police in Corregidora.

\section{Methodology}

Given the researchers' limited access to official crime statistics and the recognition that incidents of VAW reported to the police would not necessarily reflect the prevalence of VAW in a particular area, it was decided to create exploratory heat maps to understand the distribution of VAW within the urban extent of Corregidora municipality. Household surveys were designed to include questions for georeferencing locations where participants reported experiencing VAW in the public sphere. These locations were used for conducting spatial analysis to create heat maps, which in turn were used to identify specific locations to conduct site visits and visual observations for infrastructure assessment.

\section{Household surveys}

The household survey (HHS) was designed to gather data regarding sociodemographic characteristics, perceptions of community cohesion and experiences of VAW of the participants, including the time and location of incidents. The questions consisted of 13 types of $\mathrm{VAW}^{5}$, some of which are not considered crimes in Mexico, such as offensive remarks or shaming someone for being a woman. The survey questionnaire was adapted from three Mexican national surveys designed by the National Institute of Geography and Statistics of Mexico (INEGI for its acronym in Spanish) into consideration: ENDIREH (regarding household dynamics), ENVIPE (survey on victimisation and perception of safety) and ECOPRED

\footnotetext{
4 According to the methodology used by the SESNSP from 2011 until December 2017, gender-related crimes were only categorised in three types: rape, statutory rape and other sexual crimes (SESNSP 2018). Later amendments to the methodology disaggregated crimes into more categories: feminicides (subdivided depending on the weapon used -firearm, knife, another implement or unspecified), sexual abuse, sexual harassment (subdivided into general sexual harassment or harassment between a person in a similar power hierarchy or by a person in a superior power hierarchy), rape (subdivided into simple or rape by objects other than a penis, statutory rape or sexual intercourse with a person who cannot resist due to illness, loss of consciousness, disability or any other cause), incest, other crimes that threaten freedom and sexual security, family violence, and gender violence in all its forms other than family violence.

5 The list of types of violence was taken from INEGI's ENDIREH survey (INEGI 2016a), which includes: T1: Whistling or offensive sexual remarks; T2: Stalking; T3: Offended or humiliated for being a woman; T4: Ignored for being a woman; T5: Pinched, pulled hair, pushed, pulled, slapped or thrown an object; T6: Lifted skirt or dress or pulled clothes; T7: Been touched, groped, leaned against or kissed without consent; T8: Fear of being attacked or sexually abused; T9: A person showed them their private parts or touched themselves in front of them; T10: Was forced to watch porn or sexual acts; T11: Kicked or punched; T12: Attempted rape; T13: Rape.
}

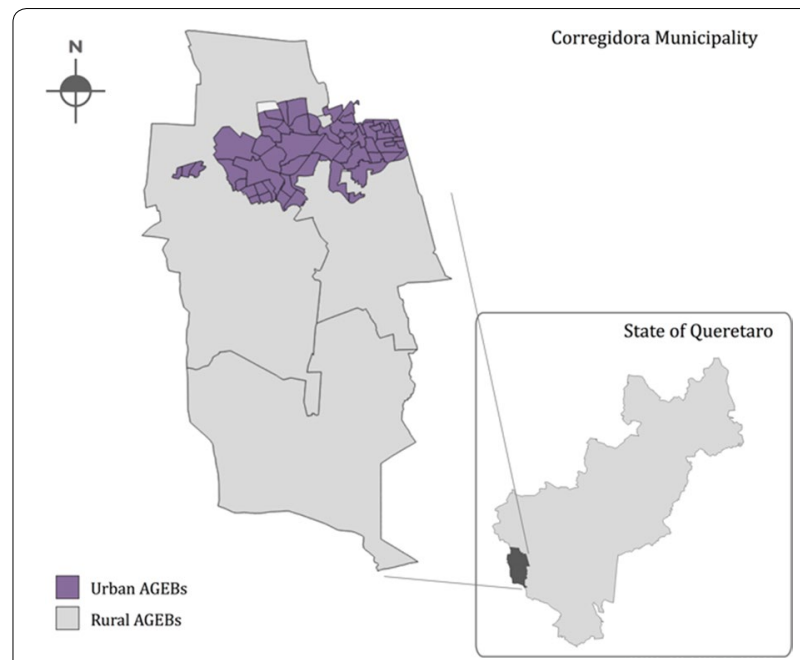

Fig. 2 Urban Agebs of Corregidora municipality (figure by the first author with maps created with shapefiles from INEGI (2015a)

(survey of social cohesion and crime prevention) (INEGI 2019a).

\section{Sample}

The sample followed a clustered sampling approach, in which the sample selection was randomised after the sample parameters had been outlined. The target population of the HHS was female residents who were 18 years of age or older from five urban localities (comprising 60 Agebs) of Corregidora (see Fig. 2). The aim of the sample selection was to understand the varied experiences of VAW that different groups of women have across the urban extent of the municipality. The sample unit of the HHS was blocks, to ensure anonymity of the respondents, with each block in the sample being represented by one woman. The sample population was based on the INEGI 2010 Population and Housing Census (INEGI 2010, 2015b). Based on the population size, a sample of 300 units (blocks) was calculated using a two-stage ${ }^{6}$ simple random sample ${ }^{7}$ with a finite population correction ${ }^{8}$ design with proportional allocation, with an additional $15 \%$ added considering no response rates. The master

\footnotetext{
${ }^{6} 20 \%$ of the initial sample was replaced because that percentage of the blocks fell within gated neighbourhoods. Most of the gated neighbourhoods denied access to the data collection team.

7 Simple random sample: $n_{0}=\frac{z^{2} p q}{e^{2}}=\frac{1.95 \times 0.4 \times 0.6}{0.05^{2}}=368.91$ where $n_{0}=$ sample size $n_{0} ; z=$ confidence level, set at $95 \% ; p=$ estimated proportion of interest, assumed to be $45 \%$, which was calculated by dividing the number of females over 20 years of age by the total population $(40,485 / 101,116)$; $\mathrm{q}=(1-\mathrm{p}) ; e=$ margin of error $(5 \%)$.

8 Finite population correction formula: $n=\frac{n_{0}}{1+\frac{n_{0}}{N}}=\frac{368.91}{1+\frac{368.91}{828}}=255.21 \times 1.15=293.49 \approx \mathbf{3 0 0}$ where $n=$ final sample size; $n_{0}=$ sample size $n_{0}$.
} 
sample of the INEGI National Housing Framework of $2016^{9}$ was used for selecting the sample blocks (INEGI 2016b). The blocks were selected randomly using a random selection formula ${ }^{10}$ in RStudio applied to the spatial data provided by the National Housing Framework of 2016 (INEGI 2016b). A random household within the selected block was chosen on site at the time of data collection $^{11}$.

\section{Data collection}

The software used for data collection was KoBo Toolbox, which allows users to download the collected data directly from the online platform. Given the sensitivity of the research, all the questions and answers were pseudonymised ${ }^{12}$ as a risk mitigating strategy in case of breach of information within the software. In order to ask the survey questions, hard copies of the survey were used, but the answers were recorded on a tablet in the tool's app. The locations were recorded using the geographic data collection option of 'area' available in the software, which allows for the use of Open Street Maps Software Development Kit to input locations as answers. The software's pre-set coordinate system was used to georeference ${ }^{13}$ the locations.

\section{Creating maps}

The HHS asked if participants had experienced 13 different types of VAW in the public sphere ${ }^{14}$ and where these incidents took place. If a participant had experiences of violence, and remembered the location, the location was registered as a polygon or a line over a

\footnotetext{
${ }^{9}$ Which reports 828 inhabited dwellings with more than one household and information regarding population (INEGI 2016b).

10 set.seed() function.

11 The selection of the household was based on convenience sampling discussed during training of data collectors. The data collectors selected houses using a combination of those easy to access taking into consideration safety issues and in most of the cases the data collectors knocked on every door of the block until there was a willing participant. There was no quota sampling. There were no call backs if participants were not home at the time of the survey, and if there were no participants found within a block, that household/block was marked as 'no response'. The HHS were applied in November of 2018, Monday to Friday from $800 \mathrm{~h}$ to $1830 \mathrm{~h}$ and Saturday and Sunday from 1000 to $1830 \mathrm{~h}$.

${ }^{12}$ E.g. They were recorded in the tool as 'Question 1' and the possible answers as options 'a', 'b', 'c', ..., with no further context.

13 "Georeferencing is the process of assigning locations to geographical objects within a geographic frame of reference" (Yao 2009). In the case of this research, the frame of reference refers strictly to a geographic coordinate system.

${ }^{14}$ The question asked if the incident occurred within the year prior to the survey. Participants were given the choice to say how many times it occurred within that year. However they were still given the choice to say if it occurred more than a year prior to the survey taking place.
}

map in a tablet ${ }^{15}$. Two programmes were used for the analysis of the spatial data and the creation of the heat maps: QGIS and RStudio. QGIS was used for clustering the incidents and RStudio was used for carrying out the density analysis and subsequent creation of heat maps. The heat maps were created at two levels: the urban extent of the municipality and cluster level, each level yielded maps showing different concentrations in different areas.

When the data was first visualised, it was found that some locations fell outside the boundaries of Corregidora municipality, which for the purposes of this researchthat focuses on the infrastructure delivery within the municipality-were irrelevant, so the features were not included in this analysis. It was also found that some polygons covered a whole neighbourhood while others marked a street corner. The difference in sizes presented a challenge for obtaining more accurate locations. It was therefore decided to use the centroids (geometric central point of a polygon or plane figure) of the polygons as point maps for creating the heat maps as a way of simplifying the process ${ }^{16}$. The centroids were determined using the QGIS Polygon centroid function.

The centroids of the polygons were also used to subset the events reported in the surveys into clusters to create heat maps at a local scale. The cluster level heat maps thus segregated the urban space and informed the decision of which locations would be visited at a later stage for carrying out observations. It was decided to aggregate the different types of VAW to create the heat maps, given the low percentage of answers with spatial data relevant for the study. Once the centroids were determined, ten clusters were generated using the QGIS K-Means clustering plugin. In terms of selecting the number of clusters, a balance was needed between geographical coverage of the clusters and number of incidents contained within the clusters. The fewer number of clusters, the larger the geographic area they covered within the municipality; on the other hand, the greater the number of clusters, the fewer incidents within the cluster. Having tested a range of number of clusters was tested (between 7 and 12), it was decided that 10 provided a balance between both factors.

\footnotetext{
${ }^{15}$ If a participant did not remember the location, she was given the option to say the type of location where the incident happened, but those answers were treated as quantitative answers.

${ }^{16}$ It was decided to use the centroids, rather than a random point or feature within the polygon, particularly for the bigger polygons, as it was determined that the centroid was a less biased coordinate than choosing a random point or feature within the polygon, as it is not possible to know where the incident occurred within the area that the participants reported.
} 
A simple density analysis was carried out in RStudio by using ggplot2 and the 2D density estimation code. Contour lines were added to show the rate of change across the surface (Mitchell, 1999). The code ${ }^{17}$ used was developed taking the work of Ellis (2018) and Collier (2013) as reference, and it yielded the map in Fig. $5^{18}$. The spatial analysis was conducted while in the field, with limited time for a thorough analysis, as decisions regarding site visits needed to be carried out within a limited timeframe. A practical method was thus required in order to carry out a quick but comprehensive analysis. This heat map method was chosen due to its simplicity and ease of implementation.

\section{Site visits and observations}

Specific locations within each cluster were then selected for site visits, in order to investigate their urban infrastructure attributes-such as roads, sidewalks, lighting and bus stops-and their delivery status and condition. This visual analysis sought to broaden the understanding provided by the mapping data by gathering on the ground information. A checklist (developed by the first author $^{19}$, see Additional file 1: Appendix for the checklist), photographs and video recordings ${ }^{20}$, were used to create methodical field notes during the site visits, and the collected data was analysed inductively. All the locations were visited during the day and night.

\section{Decision making process of site selection for observations}

The locations for site visits and visual analysis were chosen by using the previously generated clusters to divide the municipality in manageable areas that concentrated events of violence in regions. Two maps were then overlaid: the heat maps per cluster and the point maps of the polygon centroids of that cluster, which showed the type of VAW as a marker of the severity of the reported incidents (similar as shown in Fig. 5 but at cluster level). A map of the polygons as reported in the HHS that fell within the same cluster was used alongside to inform about the polygon size of the responses. These maps were used to choose one to three locations per cluster. The areas with highest concentration of incidents in the heat maps were prioritised, followed by the severity of the

\footnotetext{
${ }^{17}$ Available upon request.

18 The same code was used for each level, by changing the central coordinate and zoom number. The heat maps of each of the clusters will not be shared due to security reasons and the privacy of the victims.

19 The checklist was developed through previous experience doing transect walks in development work. A similar approach was found in the work of Crowe and Fennelly (2013).

${ }^{20}$ The video recordings were only taken at night time, as the sites were visited by car, due to safety concerns for the researcher and data collection team.
}

type of VAW that occurred at a certain location within the cluster. If a cluster had a low number of incidents, areas within the cluster that had fewer but more serious types of incidents were prioritised over areas with a higher concentration of less serious incidents. Additionally, the maps showing polygons were used to corroborate whether the clusters contained neighbourhood size polygons or a more specific location, in which case, the latter were given more importance in decision-making to conduct observations in terms of fieldwork feasibility. The geography of the site was also considered, so where several incidents were reported alongside a stretch consisting of a few blocks (no more than $200 \mathrm{~m}$ ), the entirety of the stretch was considered as a single location. Due to the limited resources available to conduct this research, where to conduct the site visits necessarily involved balancing the factors outlined above for each cluster.

\section{Results \\ Household surveys}

272 household surveys were conducted, with a response rate of $89.18 \%{ }^{21}$ (see Fig. 3 for a comparison of the age ranges for the HHS participants with the age ranges in the largest urban locality of the municipality of Corregidora). Regarding events of VAW, 167 respondents (61.39\%) expressed having experienced at least one type of violence (see Fig. 4 for a breakdown of responses per type); these 167 responses yielded a combined total of 394 events of experienced violence.

Of these 394 events, 210 (53\%) contained some form of spatial data, either a line or a polygon. Only 145 responses (37\% of the total responses, $69 \%$ of the responses with spatial data) were used for the creation of the heat maps, as these were the ones that contained information that met the criteria for creation of the maps. It must be noted that not all the participants remembered the location of the incidents of violence they experienced; and in some cases, those events took place in their home-information which the data collectors were not allowed to collect due to the data confidentiality and anonymity protocols of the study. Some women found it difficult to remember the exact location where they were victimised in public, particularly with incidents of "less serious" harassment such as catcalling and whistling ${ }^{22}$. It is also acknowledged that some women may have been reluctant to provide information about their experiences of VAW to strangers (WHO 2001, pp. 15-17).

\footnotetext{
${ }^{21} 305$ households were visited. The no response rate was of $10.82 \%$.

22 The authors have quantitative data of other locations where incidents took place (generic answers such as 'on the bus, in a park, on the street, etc'), however this information was deemed as not relevant for the purposes of this paper.
} 


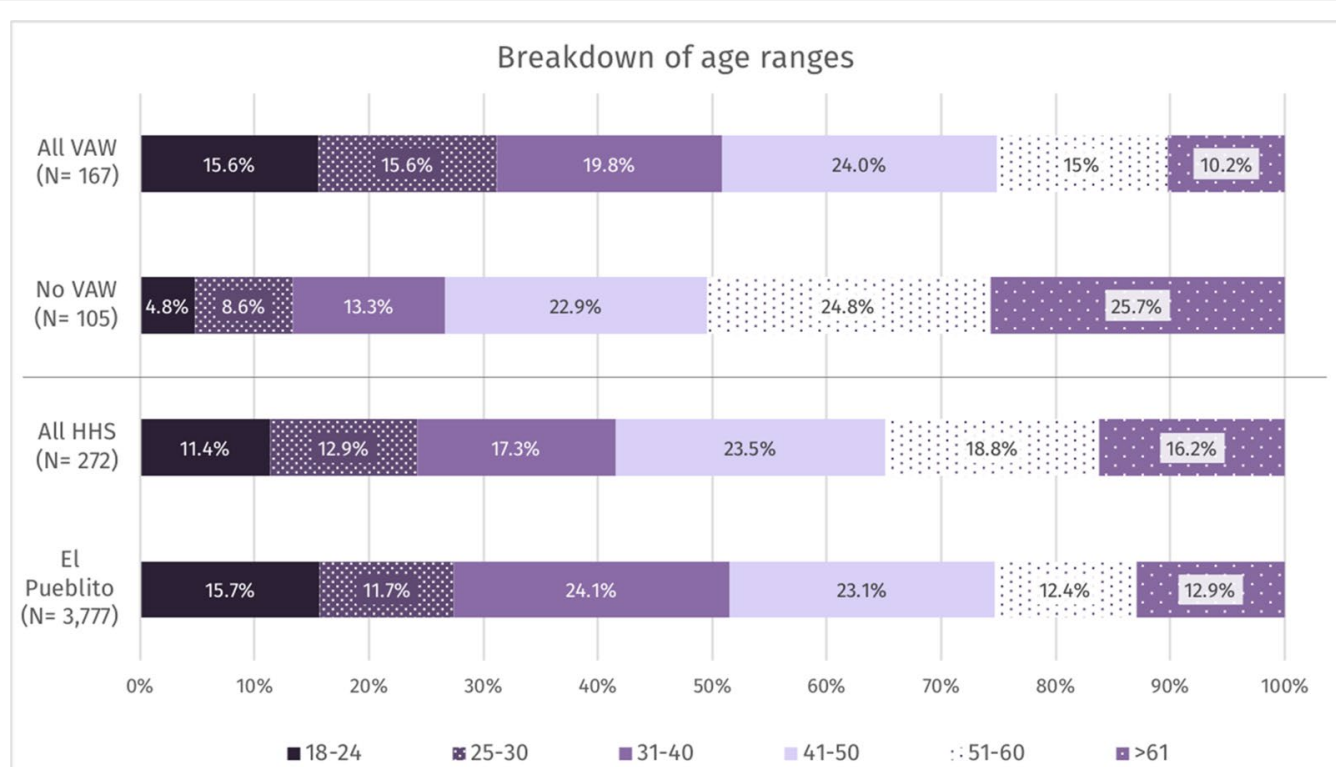

Fig. 3 Breakdown of age ranges of HHS participants (as well as those that experienced and did not experience VAW) in comparison with the age breakdown of the same age ranges of the largest urban locality of the municipality of Corregidora (El Pueblito) (Source: The first author and INEGI $(2015 c))$

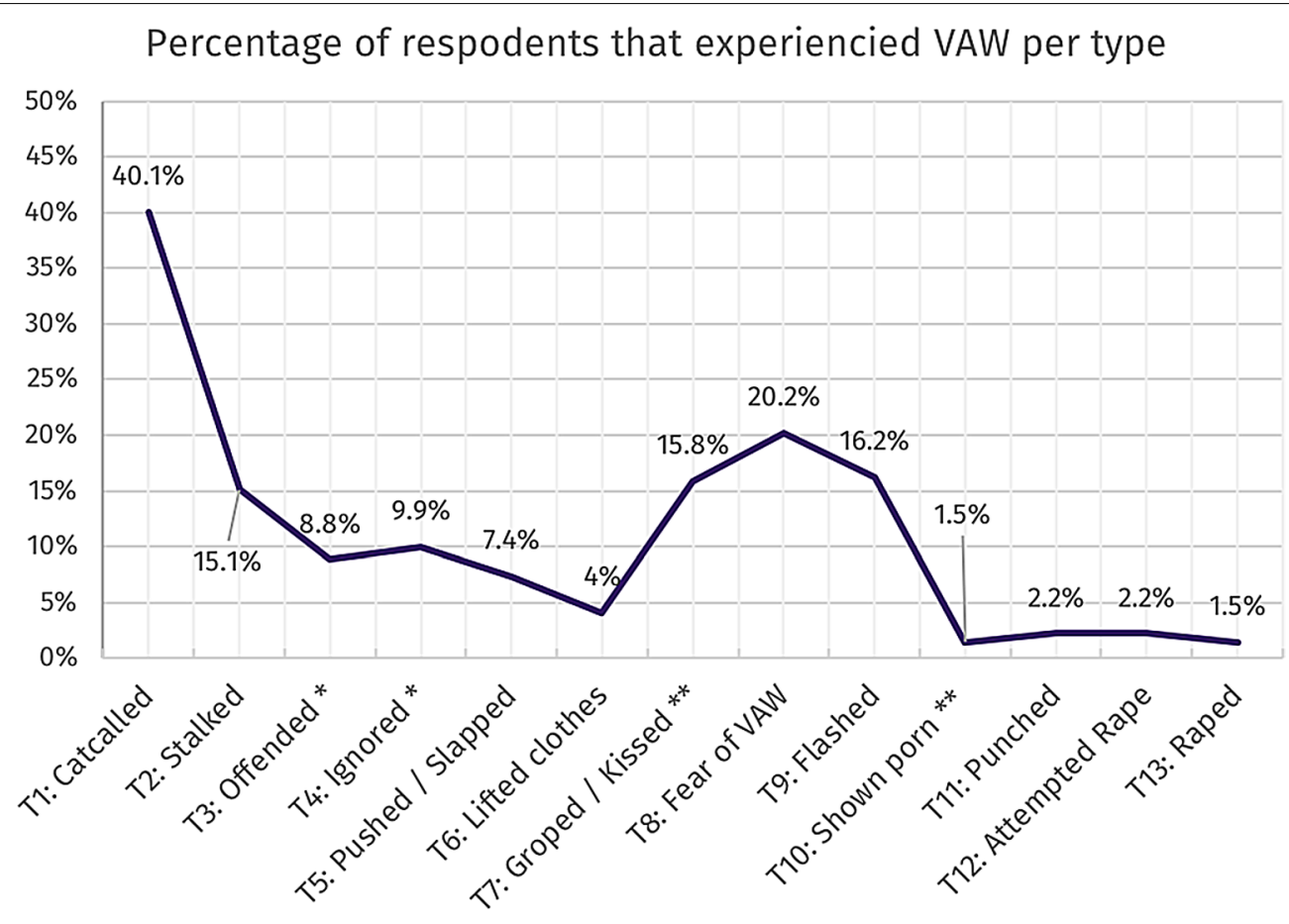

Type of incident

* for being a woman

** without consent

Fig. 4 Percentage of survey respondents that experienced VAW per type. Number of survey respondents $=272$. Figure by the first author 


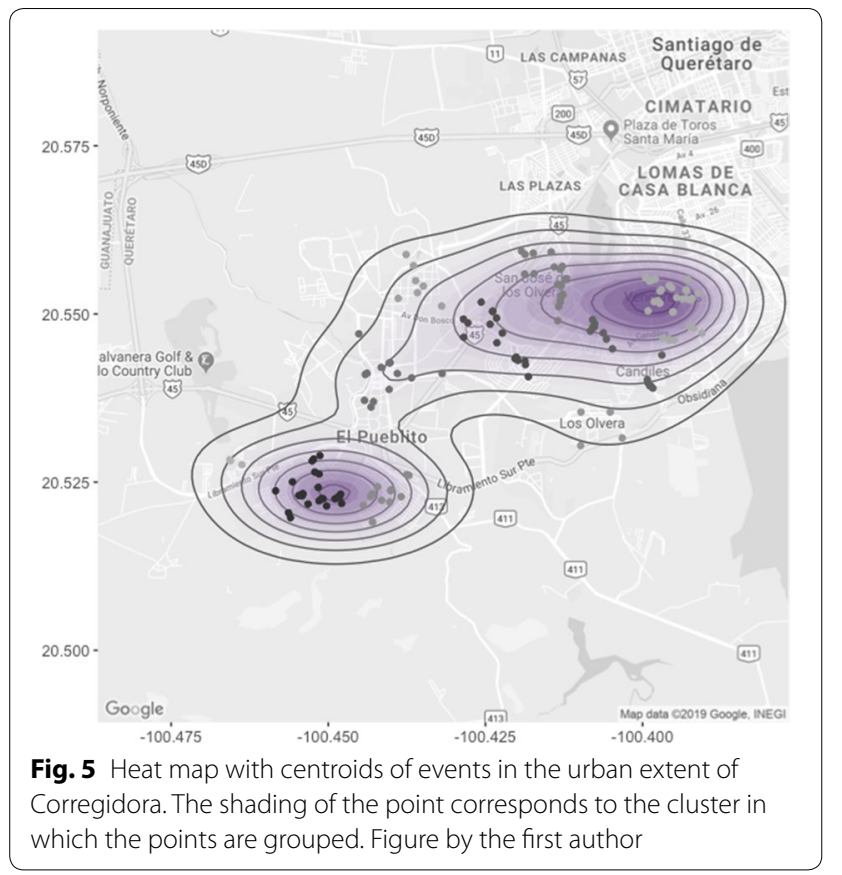

gon for this event consisted of an intersection. In those circumstances, the location where the second most serious incident took place was visited.

(c) In cluster 4, the 4 events that were reported fell within the four corners of the neighbourhood, so it was decided to visit the place where the most serious event occurred.

It is possible that for the locations with few events (i.e. locations with 3 incidents per observation) the heat maps were not necessary to identify locations, however they were subjected to the same site selection method as the rest of the areas. As for the areas with higher number of incidents, such as areas with 33 incidents (11 incidents per observation as a simplified example, see table 1), these were concentrated in clusters, hence the heat maps were a useful tool for identifying concentrations.

The 22 places that were visited were divided in three categories (see Table 2 for the breakdown of places visited):

- Roads: 13 locations (59\%),

Table 1 Number of incidents and visited locations per cluster

\begin{tabular}{llllllllll}
\hline Cluster & $\mathbf{1}$ & $\mathbf{2}$ & $\mathbf{3}$ & $\mathbf{4}$ & $\mathbf{5}$ & $\mathbf{6}$ & $\mathbf{7}$ & $\mathbf{8}$ & $\mathbf{9}$ \\
\hline $\begin{array}{l}\text { Number of incidents of VAW } \\
\begin{array}{l}\text { with spatial data } \\
\text { Visited locations }\end{array}\end{array}$ & 3 & 33 & 7 & 4 & 13 & 18 & 13 & 14 & 16 \\
\hline
\end{tabular}

\section{Maps}

The map in Fig. 5 resulted from the concentration analysis. The map presented shows the heat map created at the urban extent of the municipality, and it includes the results of all the urban localities.

\section{Site observations}

Site visits to 22 locations were carried out to conduct visual analysis. The locations were scattered throughout the 10 different clusters (see Table 1 for the number of locations visited per cluster, as well as the number of incidents with spatial data within each cluster). Clusters 3 and 4 were the only clusters in which the heat maps were not used for choosing a location within the cluster due to the following reasons:

(a) They both had a low number of incidents (7 and 4 respectively).

(b) In cluster 3, the polygon for the most serious event encompassed half of the neighbourhood, the highest concentration area did not include where the second most serious event took place, and the poly-
- Parks or plazas: 7 locations (32\%), and

- Bridges: 2 locations (9\%).

Roads

The 13 road locations were further subdivided into segments and intersections: 9 locations were street or road segments and 4 locations were street or road intersections. Of these 13 locations, 1 site had no sidewalks or road surface and the remaining 12 had narrow sidewalks ${ }^{23}$ and/or were blocked by trees, lamps and electric posts, steps or ramps leading to houses, rubbish, broken surfaces or a combination thereof, and people were observed walking on the road instead of the sidewalk.

\section{Parks/plazas}

6 of the locations were parks and 1 was a plaza. The parks varied in size-from a small local recreation area to one

\footnotetext{
${ }^{23}$ Defined as sidewalks in which only two people standing side by side fit in the surface width of the sidewalk or narrower than this.
} 
Table 2 Breakdown of locations per type

\begin{tabular}{lll}
\hline Type of area & \# of locations & \% of total \\
\hline Road & 13 & 59 \\
Segment & 9 & \\
Intersection & 4 & 32 \\
Park/plaza & 7 & \\
Park & 6 & \\
Plaza & 1 & 9 \\
Bridge & 2 & \\
\hline
\end{tabular}

of the largest city parks-and in levels of development. The parks were open throughout the day and night. At night, lighting across the parks was inconsistent and light seemed to be concentrated at the edge of the parks, particularly in the bigger parks. Notably, in one of the parks there was a large area of darkness directly behind a bus stop. These spaces provide prime opportunities, particularly after dark, when guardianship is reduced due to poor visibility.

\section{Bridges}

Both the bridges that were visited were located on the edge of a neighbourhood. The first bridge was a motorway bridge over an avenue with 4 uncovered bus stops on the 4 slip roads leading up to the motorway. It was located on the boundary of a locality, surrounded by gated communities, private schools, strip malls and empty plots. Each bus stop faced the embankment of the raised motorway and no buildings had direct views of the bus stops. There was a clear lack of guardianship, particularly after dark when the non-residential buildings were closed. The second bridge was a $125 \mathrm{~m}$ footbridge joining two neighbourhoods over an open channel. On one side, the hand rails of the bridge extended for a further $12 \mathrm{~m}$ beyond the end of the bridge to reach the road, thereby extending the $1.5 \mathrm{~m}$ wide bridge through what otherwise would have been a small open space. This appeared to be an unnecessary extension of the crime opportunities already offered by the bridge, as well as creating new ones in combination with the small open space ${ }^{24}$.

The visual checklist was useful to assess that regardless of the visited locations having vastly different features, they all:

(a) lacked/were deficient in some form of infrastructure;

\footnotetext{
${ }^{24}$ As part of the first author's Ph. D., focus group discussions were held, in which participants associated the bridge with serious incidents of VAW and other crimes.
}

(b) had physical obstacles challenging mobility and access;

(c) had spots of poor visibility at two levels:

1. private space towards public space,

2. within the public space; and

(d) were related to restricted pedestrian mobility.

\section{Lacking infrastructure}

While urban infrastructure and street furniture, such as street lamps, sidewalks or surfaced roads ${ }^{25}$, were present, they had not been delivered to completion or were lacking in their delivery. All the locations visited lacked infrastructure in some form, whether it was sidewalks, good road surfaces, pedestrian crossings, proper lighting, covered bus stops or bus stop signs. Depending on the type of infrastructure deficiency, it could act as a crime generator (such as reduced sidewalks forcing people to walk closer to each other) or reduce guardianship (such as a lack of lighting) (Belur et al. 2016; Willman and Corman 2013).

\section{Physical obstacles}

The most common feature observed in most of the sites was the inadequate space for pedestrians to transit without encountering obstacles. Most sites, including parks, lacked wide sidewalks, or sidewalks altogether in some cases. And those that had sidewalks often had lighting and electric posts built in the middle of the sidewalk, uneven and/or broken surfaces with steps, and/or rubbish, commercial goods or other types of obstacles. These obstacles can assist in the commission of crime by creating opportunities while at the same time creating spots of reduced guardianship by reducing visibility.

\section{Poor visibility}

All the locations that were visited had areas where visibility was challenged. The boundaries between public and private places were divided by long stretches of high walls or fences mostly without windows or other features that could offer signs of occupancy or which could deter crime. In the residential areas, most households chose to not exercise their guardianship abilities and self-restricting visibility by having fences or gates in front of their houses, and most windows could be observed to have closed curtains even during the day. Similarly, within the public spaces themselves, there were features hampering visibility, such as vegetation, badly placed crossings or

\footnotetext{
${ }^{25}$ For example, of the 15 sites that concerned roads (including one of the bridges), 8 were surfaced with tarmac, 4 were surfaced with cobles or brickwork, 2 with concrete and 1 (and the roads surrounding a park) were dirt roads.
} 
shops and houses encroaching on the sidewalks. These features block visibility and create blind spots which reduce guardianship.

\section{Restricted pedestrian mobility}

The layout of the sites indicated that cars were prioritised above pedestrians in terms of city planning. For example, narrow or non-existent sidewalks, few road crossings and street lighting that illuminated the road rather than the sidewalks. There appeared to be a lack of consideration for pedestrians in city planning and infrastructure design, which contributed to the creation of opportunities for crime and the reduction of guardianship, through the problematic infrastructure features identified above. This reflects how the urban layout responds to the construction of space through gender relations as well as the socio-political relationships that take place for the creation of that urban landscape.

\section{Discussion}

The fieldwork methodology presented above was intended as an early approximation to identify locations in the public urban space of the municipality of Corregidora where women experience incidents of VAW. The mapping methods were adequate for selecting locations to conduct observations and an inductive visual analysis at street level, to assess if these areas have situational factors that may influence the perpetration of VAW. This paper does not focus on the results of the application of the methods, as a control sample was not used and the possibility that these characteristics are present in other parts of the city cannot be eliminated. However, features that the crime literature suggests can provide opportunities for crime-including deficient infrastructure that reduces natural surveillance, physical obstacles that hamper visibility or reduced pedestrian mobility (LoukaitouSideris 2012; Bernasco and Block 2011; Brantingham and Brantingham 1995) - were found at the 22 locations that were visited. These spaces can be associated with providing opportunities for crime, regardless of the type of violence studied. It must be noted however that the motivations for gender-based violence have strong links to social norms, structures and subjectivities intrinsic in gender and other personal dimensions such as physical appearance, sexuality, ability and religion (Parkes 2015). And it can be argued that the normalisation and condoning of the less severe forms of violence and exclusion have contributed to the perpetuation of VAW among different societies (Frías 2016).

This methodology differs from the exercise conducted by San Román Tajonar and Meza de Luna (2019) in the methods of data collection, because HHS cover a more diverse sample of answers and therefore might lead to a more accurate reflection of real incidents, rather than answers from women who can access online resources and already have an interest in the subject. Moreover, that study did not conduct visual analysis of the sites or any other ground level analysis. Furthermore, this attempt differs from the mapping exercise carried out by the UNODC in Nuevo León (López Padilla et al. 2018) in the types of data used and the geographic level at which they were applied. The research carried out by UNODC was a state-level study that relied on official, secondary data of reported crimes. It only contemplated types of violence that are considered crimes and were reported. In a country where only an estimated $6.8 \%$ of crime incidents are reported at the national level (INEGI 2019b), official data regarding VAW is not very reliable. This research was based on a single municipality, to obtain granular information about a specific area. The data relies on first-hand accounts of different types of violence that may not necessarily be considered crimes by state or national entities, thus providing more nuanced information. Additionally, in Mexico surveys have been shown to be more reliable sources for figures of violence of this nature, as demonstrated by their use by the main institutions that report VAW in the country (OCNF 2018; SEGOB et al. 2017). It would be an interesting exercise to overlay methodologies and combine first-hand data with top level information.

Identifying factors that increase the risk of violence and victimization are important for the creation of intervention and prevention strategies (Johnson 2006). Chainey and Ratcliffe (2005) recommend integrating data to allow for a better informed and holistic view of the issue to be presented, to identify how it can be addressed in a multi-agency manner. In the case of this methodology, the identification of locations could be useful for targeting resources and programmes looking to implement, test or evaluate preventive measures or crime reduction programmes. These measures could range from infrastructure interventions to social components aiming at behavioural and social norm changes (Willman and Corman 2013) regarding VAW or a combination of both.

This study highlights the importance of georeferencing crimes, particularly VAW crimes, to inform policing and policy making at municipal level. Without this information, it is not possible to identify hotspot areas where VAW crimes are being committed. The government of Mexico City is an example at national level of how crime data can be georeferenced in the country. However it is not clear how this information is being used to inform planning or the design of urban infrastructure at the local level.

More testing is needed in order to state with some level of certainty that the absence of infrastructure is a significant facilitator for VAW. Nonetheless, the literature and 
this study can support the broader point that designing spaces that include gender inclusive recommendations can improve women's safety in public places. Integrating gender inclusive recommendations into urban development should address meeting women's needs, as these are critical for promoting sustainable and equitable urban development that responds equally to women and men (Whitzman et al. 2013; Khosla 2009). Failure to address gender inequality in the urban space can lead to the reinforcement of oppressive roles and restricted mobility. In the case of the municipality of Corregidora, each identified cluster seemed to face different issues ranging from lighting, sidewalk sizing to city planning. Therefore it would be important to understand in more detail the concerns of the neighbouring residents for the creation of targeted programmes.

\section{Limitations, challenges and data gaps}

The data that was used for the creation of the maps was based on notations over a surveying map available at Kobo Toolbox. Thus the data needs to be cross-referenced and validated by overlaying it with official data, crime statistics or other independent studies, especially if conclusions of criminogenic areas or hotspots are to be drawn. Additionally, some features that were recorded during the HHS were not used for the creation of the maps, including line features that fell within the boundaries of the municipality. The method would have been better informed by using this data.

The calculations for creating the maps were based on the pre-programmed density values built into the used $R$ package, including cell size, bandwidth or search radius and the calculation method in itself $^{26}$. The maps therefore show no statistical significance of the sites. This is particularly troublesome as patterns may be too generalised, showing concentration levels in areas where no incidents took place or smoothing out more criminogenic areas (Chainey and Ratcliffe 2005). Moreover, the limitations of the clustering method include its requirement for the number of clusters to be specified in advance and forcing all the data to be included within a cluster (Vickers and Rees 2007; Ester et al. 1996). This creates difficulties in relation to isolated data points which may skew the results of the overall heat map. These limitations can be overcome in future studies by using methods that quantitatively weight point, line and possibly aerial data.

\footnotetext{
${ }^{26}$ Cell size determines how fine or coarse the patterns appear. It is suggested to set the cell size between 10 and 100 cells per density unit. Bandwidth determines the coefficient of density. There are two types of calculation methods: (1) Simple method: counts only those features within the search radius of each cell. (2) Weighted method: uses a mathematical function to give more importance to features beyond the search radius (Kulyk and Sossa 2018; Mitchell 1999).
}

This could be achieved through the use of more complex codes that allow for parameter manipulation (which can be useful for giving more importance to incidents that are considered crimes, for example), plugins included in Geographic Information Systems (GIS) software, or more advanced packages imported to GIS software (Bowers et al. 2004). Experimentation with other types of clustering may also lead to improved results. For example, density-based clustering methods, like DBSCAN could be used, which allow for the identification of clusters with arbitrary shapes and ignore noise (Ester et al. 1996). The intent of this study was not to establish statistical significance of hotspots but rather to provide an overall view of where violence may be taking place, particularly where no other data is available, in circumstances where quick results are needed or there is lack of resources.

Further analysis and testing of the methodology (which include incorporating a control sample) is needed to understand whether the features of the urban built environment identified during the site visits have a correlation with the perpetration of VAW. However, the findings suggest there could be an influence on crime occurrence, as infrastructure features providing opportunities for crime were found in all the visited locations. A final limitation of this study is that despite calculating a geographically random sample, it was not possible to represent the experiences of every woman in the municipality. The experiences of women living in periurban areas may have been overlooked by not including neighbouring rural areas of the city. According to the maps used for the sampling of this study (INEGI 2015a), the urban Agebs cover only $12.2 \%$ of the extent of the municipality. The implications of not including Agebs considered rural may mean that some neighbourhoods or communities, and the experiences of the women living there, that are now part of the periurban areas due to the urban sprawl were not considered. More studies are needed to integrate the experiences of women living in different parts of the urban environment.

\section{Conclusions}

The methodology presented in this paper was useful to support the rapid identification of pockets of locations where women appeared to be more vulnerable to gender violence in the streets of Corregidora in Querétaro, Mexico. The heat maps generated with household data were useful for identifying locations to conduct structured observations and inductive visual analysis at street level in order to understand if these areas have additional situational factors regarding elements of the urban built environment, such as road typology, lacking infrastructure, physical obstacles and reduced pedestrian mobility, that may influence the perpetration of 
Violence Against Women (VAW). The methodology can be reproduced by organisations in areas with poor crime recording practices that have limited budgets for mapping technologies or limited expertise in Geographic Information Systems, although it requires a basic level of spatial reasoning and understanding of Geographic Information, as well the ability to use a software with integrated mapping tools. Further research on this methodology and its application could explore in-depth spatial analysis allowing for the advanced manipulation of multiple variables and for the discrimination of areas identified as relevant based on tests of statistical significance. This methodology however incorporates data that would not have been available from official government datasets as some of the types of VAW included in the household data may not be considered crimes and, in any event, many crimes go unreported.

\section{Supplementary information}

Supplementary information accompanies this paper at https://doi. org/10.1186/s40163-020-00125-6.

Additional file 1. Observations and visual data checklist.

\section{Abbreviations}

Agebs: Basic geostatistical areas; CPTED: Crime Prevention Through Environmental Design; ENDIREH: National Survey on the Dynamics of Household Relations; GIS: Geographic information systems; HHS: Household survey; INEGI: National Institute of Geography and Statistics; OCQ: Observatorio Ciudadano de Querétaro; SESNSP: Mexican Secretariat of Public Security; UNODC: United Nations Office on Drug and Crime; VAW: Violence against women.

\section{Acknowledgements}

The authors would like to thank Dr. James Haworth of the Department of Civil, Environmental and Geomatic Engineering and Dr. Lisa Tompson of the Department of Security and Crime Science of UCL for their comments and advice on some of the methods presented in this paper. We would also like to thank Nicholas Lee and Loan Diep for their thorough proofreading and valuable comments on the manuscript. We are very grateful to the data collectors for their hard work in conducting the household surveys. And last but not least, thank you to all the participants who made this work possible.

\section{Authors' contributions \\ MGR contributed to the conceptualisation of the project, design, implemen- tation of the research and analysis of the results. MGR wrote the manuscript with the input and support of PP and JB. PP and JB provided support in the conceptualisation of the project and research design, supported and reviewed the methodology and tools for data collection and contributed to the peer- reviewed expert process. PP supervised the project as well as and provided support in ethical clearance. JB co-supervised the project and provided guidance for data analysis methods. All authors read and approved the final manuscript.}

\section{Funding}

This work was possible thanks to support of the Consejo Nacional de Ciencia y Tecnología CONACyT (the National Council of Science and Technology) of Mexico and University College London, which funded the Ph. D. programme where this paper derived from.

\section{Availability of data and materials}

Given the sensitivity of the topic and the data, as well as the ethical procedures that were followed for this research, the authors considered that some datasets used for this article can be provided upon request. These datasets include overall victimisation statistics and the coding for the methodology. If you are interested in this documentation, please contact ucesamg@ucl.ac.uk.

\section{Ethics approval and consent to participate}

This research raises ethical challenges regarding violence and working with potentially vulnerable people that experienced violence, therefore ethical considerations and agreements were taken seriously. These considerations included obtaining ethical approval by the UCL Ethics Committee (Project No. 9277/003), ensuring coverage of the project by the UCL Data Protection Registration (Reference No. Z6364106/2018/05/118 social research) and obtaining local permission to conduct the research, which consisted of the ethical approval of the project from a local university (Universidad Autónoma de Querétaro, Project No. DIP/573-18). Participants were explained the purpose of the research and what the data would be used for; asked to sign a consent form before starting the household survey; and the survey only took place if the participant was on their own. Surveys were terminated when participants did not wish to continue and all data was anonymized.

\section{Competing interests}

There are no competing interests that the authors are aware of.

\section{Author details}

${ }^{1}$ Engineering for International Development Centre and Civil, Environmental and Geomatic Engineering, University College London, London, UK. ${ }^{2}$ Department of Security and Crime Science, University College London, London, UK.

Received: 13 December 2019 Accepted: 28 July 2020

Published online: 06 August 2020

\section{References}

Ariel, B., \& Partridge, H. (2017). Predictable policing: Measuring the crime control benefits of hotspots policing at bus stops. Journal of Quantitative Criminology, 33(4), 809-833. https://doi.org/10.1007/s10940-016-9312-y.

Banda Campos, L. (2017). Crece tasa poblacional en Corregidora al 8\%. El Diario de Querétaro. Retrieved from https://www.diariodequeretaro.com.mx/ local/crece-tasa-poblacional-en-corregidora-al-8-451441.html.

Banda Campos, L. (2019). Corregidora crece al 6\% anual: Sosa - Diario de Querétaro. Retrieved from https://www.diariodequeretaro.com.mx/local/corre gidora-crece-al-6-anual-sosa-3861338.html.

Belur, J., Parikh, P., Daruwalla, N., Joshi, R., \& Fernandes, R. (2016). Perceptions of gender-based violence around public toilets in Mumbai slums. International journal of comparative and applied criminal justice, 41(1-2), 63-78.

Bernasco, W., \& Block, R. (2011). Robberies in Chicago: A block-level analysis of the influence of crime generators, crime attractors, and offender anchor points. Journal of Research in Crime and Delinquency, 48(1), 33-57. https:// doi.org/10.1177/0022427810384135.

Bhattacharyya, R. (2016). Street violence against women in India: Mapping prevention strategies. Asian Social Work and Policy Review, 10(3), 311-325. https://doi.org/10.1111/aswp.12099.

Bowers, K. J., Johnson, S. D., \& Pease, K. (2004). Prospective hot-spotting: The future of crime mapping? British Journal of Criminology, 44(5), 641-658. https://doi.org/10.1093/bjc/azh036.

Brantingham, P. J., \& Brantingham, P. L. (Eds.). (1981). Environmental Criminology. Beverly Hills: SAGE Publications.

Brantingham, P. J., \& Brantingham, P. L. (1995). Criminality of place. European Journal on Criminal Policy and Research, 3(3), 5-26. https://doi. org/10.1007/BF02242925

Calderón, L.Y., Heinle, K., Ferreira, O. R., \& Justice, D. A. S. (2019). Organized Crime and Violence in Mexico. Justice in Mexico. San Diego. Retrieved from https://www.justiceinmexico.org

Ceccato, V., \& Paz, Y. (2017). Crime in São Paulo's metro system: Sexual crimes against women. Crime Prevention and Community Safety, 19(3-4), 211-226. https://doi.org/10.1057/s41300-017-0027-2.

Chainey, S., \& Ratcliffe, J. (2005). GIS and Crime Mapping. Chichester, West Sussex: Wiley. 
Chui, W. H., \& Ong, R. (2008). Indecent assault on the public transport in Hong Kong. International Journal of Law, Crime and Justice, 36(1), 2-14. https:// doi.org/10.1016/j.ijsl.2007.06.001.

Collier, A. B. (2013). Contour and Density Layers with ggmap. Retrieved from https://datawookie.netlify.com/blog/2013/12/contour-and-density-layer s-with-ggmap/.

Cornish, D. B., \& Clarke, R. V. G. (1986). The Reasoning Criminal: Rational Choice Perspectives on Offending. New York: Springer.

Council of Europe. (2011). Council of Europe Convention on preventing and combating violence against women and domestic violence. Istanbul: Council of Europe. Retrieved from https://rm.coe.int/168046031c

Crowe, T. D., \& Fennelly, L. J. (2013). Crime Prevention Through Environmental Design (Third Edit). Elsevier. https://doi.org/10.1016/C2012-0-03280-2.

Cubbage, C. J., \& Smith, C. L. (2009). The function of security in reducing women's fear of crime in open public spaces: A case study of serial sex attacks at a Western Australian university. Security Journal, 22(1), 73-86. https://doi.org/10.1057/sj.2008.12.

Dunckel-Graglia, A. (2013). Women-only transportation: How "pink" public transportation changes public perception of women's mobility. Journal of Public Transportation, 16(2), 85-105. https://doi. org/10.5038/2375-0901.16.2.5.

Dymén, C., \& Ceccato, V. (2012). An international perspective of the gender dimension in planning for urban safety. In C. Vania (Ed.), The Urban Fabric of Crime and Fear (pp. 311-339). Dordrecht: Springer. https://doi. org/10.1007/978-94-007-4210-9_13.

Eck, J. E. (1994). Drug Markets and Drug Places: A Case-control Study of the Spatial Structure of Illicit Drug Dealing. Doctoral dissertation, University of Maryland College Park, USA.

Eck, J. E., Chainey, S., Cameron, J. G., Leitner, M., \& Wilson, R. E. (2005). Mapping Crime: Understanding Hot Spots. Washington DC: U.S. Department of Justice Office of Justice Programs.

Ellis, L. (2018). Map Plots Created With R and Ggmap. Retrieved from https:// www.littlemissdata.com/blog/maps.

Ester, M., Kriegel, H.-P., Sander, J., \& Xu, X. (1996). A Density-Based Algorithm for Discovering Clusters in Large Spatial Databases with Noise. In KDD'96: Proceedings of the Second International Conference on Knowledge Discovery and Data Mining (pp. 226-231). Retrieved from https://www.aaai.org.

Farrington, D. P., \& Welsh, B. C. (2002). Improved Street Lighting and Crime Prevention. Justice Quarterly, 19(2), 313-342. Retrieved from https:// www.tandfonline.com/doi/pdf/10.1080/07418820200095261?needA ccess $=$ true

Felson, M., \& Clarke, R. V. (1998). Opportunity Makes the Thief: Practical theory for crime prevention (Police Research Series No. 98). London.

FGJ CDMX. (2020). Estadisticas Delictivas. Retrieved from https://www.fgjcd $m \times . g o b . m x /$ procuraduria/estadisticas-delictiva.

Fontes, K. B., Carolina, A., Alarcão, J., Nihei, O. K., Pelloso, S. M., Andrade, L., et al. (2018). Regional disparities in the intimate partner sexual violence rate against women in Paraná State, Brazil, 2009-2014: an ecological study. British Medical Journal Open, 8(2), 1-8. https://doi.org/10.1136/bmjop en-2017-018437.

Foster, S., \& Giles-Corti, B. (2008). The built environment, neighborhood crime and constrained physical activity: An exploration of inconsistent findings. Preventive Medicine, 47, 241-251. https://doi.org/10.1016/j.ypmed 2008.03.017.

Frías, S. M. (2016). Violentadas. Nexos. Retrieved from https://www.nexos.com. $m x / ? p=28501$.

Gekoski, A., Gray, J. M., Adler, J. R., \& Horvath, M. A. H. (2017). The prevalence and nature of sexual harassment and assault against women and girls on public transport: an international review. Journal of Criminological Research, Policy and Practice, 3(1), 3-16. https://doi.org/10.1108/JCRPP -08-2016-0016.

Gobierno de CDMX. (2020). Carpetas de investigación FGJ de la Ciudad de México. Retrieved from https://datos.cdmx.gob.mx/explore/dataset/ carpetas-de-investigacion-pgj-de-la-ciudad-de-mexico/map/?disjunctiv e.ao_hechos\&disjunctive.delito\&location $=11,19.35365,-99.13271$.

Gupte, J., Bogati, S., Lind, J., \& Schultze-Kraft, M. (2014). Key Challenges of Security Provision in Rapidly Urbanising Contexts: Evidence from Kathmandu Valley and Terai Regions of Nepal. Brighton. Retrieved from https://opend ocs.ids.ac.uk/opendocs/bitstream/handle/20.500.12413/3881/ER69\%20 Key\%20Challenges\%20of\%20Security\%20Provision\%20in\%20Rapidly\%20
Urbanising\%20Context\%20Evidence\%20from\%20Kathmandu\%20Val ley\%20and\%20Terai\%20Regions\%20of\%20Nepal.pdf?sequence=1. Harassmap. (2020). Harassmap. Retrieved from https://harassmap.org/en/. Hong, J., \& Chen, C. (2014). The role of the built environment on perceived safety from crime and walking: examining direct and indirect impacts. Transportation, 41, 1171-1185. https://doi.org/10.1007/s1111 6-014-9535-4.

Instituto Nacional de Estadística y Geografía (INEGI). (2010). Censo de Población y Vivienda 2010. INEGI. Instituto Nacional de Estadística y Geografía (INEGI). Retrieved from http://www.inegi.org.mx/est/scince/scince2010.aspx?_ file $=/$ est/scince/scince2010/Scince2010_\$FILENUM.exe\&idusr $=8008 \overline{5}$.

Instituto Nacional de Estadística y Geografía (INEGI). (2015a). Cartografía Geoestadística Urbana y Rural Amanzanada. Cierre de la Encuesta Intercensal 2015.

Instituto Nacional de Estadística y Geografía (INEGI). (2015b). Encuesta Intercensal 2015. Retrieved from http://www.beta.inegi.org.mx/proyectos/encho gares/especiales/intercensal/.

Instituto Nacional de Estadística y Geografía (INEGI). (2015c). Microdatos. Encuesta Intercensal 2015. Retrieved from https://www.inegi.org.mx/progr amas/intercensal/2015/default.html\#Microdatos.

Instituto Nacional de Estadística y Geografía (INEGI). (2016a). Encuesta Nacional sobre la Dinámica de las Relaciones en los Hogares 2016. Mexico City. Retrieved from http://www.beta.inegi.org.mx/proyectos/enchogares/ especiales/endireh/2016/.

Instituto Nacional de Estadística y Geografía (INEGI). (2016b). Inventario Nacional de Viviendas (INV). Retrieved July 23, 2018, from http://www. beta.inegi.org.mx/app/mapa/inv/.

Instituto Nacional de Estadística y Geografía (INEGI). (2017). Boletín de Prensa Núm. 379/17: Resultados de la Encuesta Nacional Sobre la Dinámica de las Relaciones en los Hogares (ENDIREH) 2016. Instituto Nacional de Estadística y Geografía (INEGI), pp. 1-20. Retrieved from http://www.inegi.org.mx/ saladeprensa/boletines/2017/endireh/endireh2017_08.pdf.

Instituto Nacional de Estadística y Geografía (INEGI). (2019a). Instituto Nacional de Estadística y Geografía. Retrieved from https://www.inegi.org.mx/.

Instituto Nacional de Estadística y Geografía (INEGI). (2019b). Encuesta Nacional de Victimización y Percepción sobre Seguridad Pública (ENVIPE) Principales Resultados. Mexico City. Retrieved from https://www.inegi.org.mx/conte nidos/programas/envipe/2019/doc/envipe2019_presentacion_nacional. pdf.

Johnson, H. (2006). Measuring violence against women: Statistical Trends 2006 (No. 85-570-XWE). Ottawa. Retrieved from http://www.statcan.gc.ca/ pub/85-570-x/85-570-×2006001-eng.htm?contentType=applicatio n\%2Fpdf.

Khosla, R. (2009). Addressing Gender Concerns in India's Urban Renewal Mission. New Delhi. Retrieved from http://www.undp.org/content/dam/india/ docs/addressinggenderconcerns.pdf.

Kim, Y., \& Zangerling, B. (2016). Mexico Urbanization Review: Managing Spatial Growth for Productive and Livable Cities in Mexico. Washington, D.C. Retrieved from http://elibrary.worldbank.org/doi/ book/10.1596/978-1-4648-0916-3

King, R. (2009). Women's fear of crime on university campuses: New directions? Security Journal, 22(1), 87-99. https://doi.org/10.1057/sj.2008.14.

Kulyk, V., \& Sossa, R. (2018). Determining the tourist attractive regions by gis analysis using heatmaps. Geodesy and Cartography, 44(1), 22-27. https:// doi.org/10.3846/gac.2018.882.

Leclerc, B., Chiu, Y. N., Cale, J., \& Cook, A. (2016). Sexual violence against women through the lens of environmental criminology: Toward the accumulation of evidence-based knowledge and crime prevention. European Journal on Criminal Policy and Research, 22(4), 593-617. https://doi. org/10.1007/s10610-015-9300-z.

Leong, K., \& Chan, S. C. F. (2013). A content analysis of web-based crime mapping in the world's top 100 highest GDP cities. Crime Prevention and Community Safety, 15(1), 1-22. https://doi.org/10.1057/cpcs.2012.11.

Levy, C. (2013). Travel choice reframed: "Deep distribution" and gender in urban transport. Environment and Urbanization, 25(1), 47-63. https://doi. org/10.1177/0956247813477810.

López Padilla, I., Mobayed, S., \& Chambon, L. (2018). Mapa Georreferenciado de la Violencia Contra las Mujeres en el Estado de Nuevo Leon 2008-2017. Mexico City.

Loukaitou-Sideris, A. (2012). Safe on the Move: The Importance of the Built Environment. In V. Ceccato (Ed.), The Urban 
Fabric of Crime and Fear (pp. 85-110). Stockholm: Springer. https://doi. org/10.1007/978-94-007-4210-9_4.

Loukaitou-Sideris, A. (2016). A gendered view of mobility and transport: Next steps and future directions. Town Planning Review, 87(5), 547-565. https:// doi.org/10.3828/tpr.2016.38.

Manazir, S. H., Govind, M., \& Rubina, (2019). My safetipin mobile phone application: Case study of e-participation platform for women safety in India. Journal of Scientometric Research, 8(1), 47-53. https://doi.org/10.5530/jscir es.8.1.7.

Massey, D. B. (1994). Space, Place and Gender. Polity Press. Retrieved from https ://ebookcentral.proquest.com/lib/ucl/detail.action?doclD $=1584059$.

Mazeika, D. M., \& Sumit Kumar, B. (2017). Do crime hot spots exist in developing countries? Evidence from India. Journal of Quantitative Criminology, 33, 45-61. https://doi.org/10.1007/s10940-016-9280-2.

Mazumder, H., \& Pokharel, B. (2019). Journal of aggression, maltreatment \& trauma sexual violence on public transportation: A threat to women's mobility in Bangladesh. Journal of Aggression, Maltreatment \& Trauma, 28(8), 1017-1019. https://doi.org/10.1080/10926771.2018.1491487.

Mcllwaine, C. (2013). Urbanization and gender-based violence: Exploring the paradoxes in the global South. Environment and Urbanization, 25(1), 65-79. https://doi.org/10.1177/0956247813477359.

Mitchell, A. (1999). The ESRI Guide to GIS Analysis, Volume 1: Geographic Patterns \& Relationships. Redlands, California: Environmental Systems Research Institute, Inc.

Mohamed, A. A., \& Stanek, D. (2019). Street networks, pedestrian movement patterns and sexual harassment. Journal of Gender-Based Violence, 3(1), 7-28. https://doi.org/10.1332/239868019x15475690989380.

Muldoon, K. A., Galway, L., Reeves, A., Leach, T., Heimerl, M., \& Sampsel, K. (2019). Geographies of sexual assault: A spatial analyses to identify neighborhoods affected by sexual and gender-based violence. Journal of Interpersonal Violence. https://doi.org/10.1177/0886260519851175.

Natarajan, M., Clarke, R., Carcach, C., Ponce, C., Beneke De Sanfeliú, M., Polanco, D. E., et al. (2015). Situational prevention and public transport crime in El Salvador. Crime Science, 4(1), 1-15. https://doi.org/10.1186/s4016 3-015-0043-4.

Natarajan, M., Schmuhl, M., Sudula, S., \& Mandala, M. (2017). Sexual victimization of college students in public transport environments: A whole journey approach. Crime Prevention and Community Safety, 19(3-4), 168-182. https://doi.org/10.1057/s41300-017-0025-4.

Newton, A. D. (2014). Crime on Public Transport. Berlin: Springer.

Observatorio Ciudadano Nacional del Feminicidio (OCNF). (2018). Implementación del Tipo Penal de Feminicidio en México: Desafíos para Acreditar las Razones de Género 2014-2017. Mexico City. Retrieved from https://92eab 0f5-8dd4-485d-a54f-b06fa499694d.filesusr.com/ugd/ba8440_66cc5 ce03ac34b7da8670c37037aae9c.pdf.

Observatorio Ciudadano Querétaro (OCQ). (2018). Resultado de la cuarta evaluación. Municipio de Corregidora. Querétaro. Retrieved from http://ocq. mx/wp-content/uploads/2018/04/Resultados_kuri.pdf.

Observatorio Ciudadano Querétaro (OCQ). (2019). Evaluación Ciudadana Semestral 01-2019. Municipio de Corregidora. Retrieved from http://ocq. mx/wp-content/uploads/2019/10/Reporte-Evaluación-01S19-Municipiode-Corregidora-Tipografia-2.pdf.

Oreskovic, N. M., Roth Suzanne Lanyi Charles, P., Tsigaridi Kathrine Shepherd, D., Nelson, K. P., \& Bar, M. (2014). Attributes of form in the built environment that influence perceived walkability. Journal of Architectural and Planning Research, 31(3), 218-232. Retrieved from https://www.ncbi.nlm.nih. gov/pmc/articles/PMC4278351/pdf/nihms-647632.pdf

Parikh, P., Fu, K., Parikh, H., Mcrobie, A., \& George, G. (2015). Infrastructure provision, gender, and poverty in Indian slums. World Development, 66, 468-486. https://doi.org/10.1016/j.worlddev.2014.09.014.

Parkes, J. (2015). Theory and diagnostics: Introduction. In J. Parkes (Ed.), Gender Violence in Poverty Contexts: The Education Challenge (pp. 3-10). Oxon: Routledge.

Regional Office for Central America of the United Nations High Commissioner for Human Rights (OHCHR), \& ONU Mujeres. (2014). Latin American Model Protocol for the investigation of gender-related killings of women (femicidel feminicide). Ciudad Mexico. Retrieved from http://endviolence.un.org/ pdf/LatinAmericanProtocolForlnvestigationOfFemicide.pdf.

Rossmo, D. K. (2014). Geographic profiling. Encyclopedia of Criminology and Criminal Justice (pp. 1934-1942). New York: Springer. https://doi. org/10.1007/978-1-4614-5690-2_678.
Safetipin. (2020). Safetipin. Retrieved from http://safetipin.com.

Salguero, M. (2019). Los feminicidios en México. Retrieved from https://femin icidiosmx.crowdmap.com/.

San Román Tajonar, G., \& Meza de Luna, M. E. (2019). Geografía del acoso callejero en Querétaro. Revista de Análisis de Arte, Ciencia y Cultura Multidisciplinario, 11(20), 9-18. Retrieved from https://www.delitoenqu eretaro.com

Secretaría de Desarrollo Social (SEDESOL). (2019). Catálogo de Localidades. Retrieved from http://www.microrregiones.gob.mx/catloc/LocdeMun. aspx?tipo $=$ clave $\&$ campo $=$ oc\&ent $=22 \&$ mun $=006$.

Secretariado Ejecutivo del Sistema Nacional de Seguridad Pública (SESNSP). (2018). Formato del nuevo Informe Policial Homologado. Retrieved from https://www.gob.mx/sesnsp/articulos/formato-del-nuevo-informe-polic ial-homologado.

Serendipia. (2019). Mapa de intentos de secuestro en Ciudad de México y Estado de México. Retrieved from https://serendipia.digital/2019/01/mujerescomparten-historias-sobre-intentos-de-secuestro-en-ciudad-de-mexic o-y-estado-de-mexico-mapa/.

Shepherd, L. J. (2008). Gender, Violence \& Security: Discourse as Practice. London: Zed Books.

Smith, M. J. (2008). Addressing the security needs of women passengers on public transport. Security Journal, 21(1-2), 117-133. https://doi. org/10.1057/palgrave.sj.8350071.

SEGOB, Inmujeres, \& ONU Mujeres. (2017). La Violencia Feminicida en México: Aproximaciones y Tendencias 1985-2016. Mexico City. Retrieved from https ://www.gob.mx/cms/uploads/attachment/file/293666/violenciaFemini cidaMx_07dic_web.pdf.

Tripathi, K., Borrion, H., \& Belur, J. (2017). Sexual harassment of students on public transport: An exploratory study in Lucknow, India. Crime Prevention and Community Safety, 19, 240-250. https://doi.org/10.1057/s4130 0-017-0029-0.

United Nations (UN). (1993). Vienna Declaration and Programme of Action. Vienna: United Nations. Retrieved from http://www.ohchr.org/Docum ents/Professionallnterest/vienna.pdf.

Valle-Jones, D. (2019). Crimen por tu Rumbo. Retrieved from https://hoyodecrim en.com.

Vickers, D., \& Rees, P. (2007). Creating the UK National Statistics 2001 output area classification. Journal of the Royal Statistical Society: Series A, 170(2), 379-403.

Weisburd, D. (2015). The law of crime concentration and the criminology of place. Criminology, 53(2), 133-157. https://doi.org/10.1111/17459125.12070.

Wesely, J. K., \& Gaarder, E. (2004). The gendered "Nature" of the urban outdoors: Women negotiating fear of violence. Source: Gender and Society, 18(5), 645-663. https://doi.org/10.1177/0891243204268127.

Whitzman, C., Legacy, C., Andrew, C., Klodawsky, F., Shaw, M., \& Viswanath, K. (Eds.). (2013). Building Inclusive Cities: Women's Safety and the Right to the City. Journal of Chemical Information and Modeling. London: Routledge. https://doi.org/10.1017/CBO9781107415324.004

Willman, A. M., \& Corman, C. (2013). Sexual and Gender-Based Violence: What is the World Bank Doing, and What Have We Learned? A Strategic Review. Washington D.C. Retrieved from http://documents.worldbank.org/curat ed/en/643311468332684526/pdf/832090WP0sexuaOBox0382076B00PU BLIC0.pdf.

World Health Organization (WHO). (2001). Putting Women First. Geneva: World Health Organization. https://doi.org/10.1207/s15327019eb1402.

Yao, X. (2009). Georeferencing, geocoding. International Encyclopedia of Human Geography (pp. 458-465). Amsterdam: Elsevier. https://doi.org/10.1016/ b978-008044910-4.00448-x.

Yu, C., \& He, Z.-C. (2017). Analysing the spatial-temporal characteristics of bus travel demand using the heat map. Journal of Transport Geography, 58, 247-255. https://doi.org/10.1016/j.jtrangeo.2016.11.009.

\section{Publisher's Note}

Springer Nature remains neutral with regard to jurisdictional claims in published maps and institutional affiliations. 